\title{
Assessing Public Administration and Image Making Efficiency in the Region Taking Into Consideration Quality of Managing Black Economy
}

\author{
Novenkova A.A. a \\ Antonova N.V. b \\ a,b Kazan Federal University, Kazan, 420008, Russia
}

\section{Doi:10.5901/mjss.2014.v5n12p167}

\begin{abstract}
The article contributes to the existing system to assess efficiency of regional executive authorities. It involves factors defining regional development outlook in terms of efficiency, effectiveness and quality of managing hidden economy as well as judicial and legislative power. It develops general guidelines to improve regional public management in the course of establishing computer oriented society. The fundamental principle is that we should increase access to information related to performance and expand the system to manage meso-scale development. The article sets out methods to increase the performance of public management feedback system using open information area.
\end{abstract}

Keywords: regional economy, public management, regional image, black economy, management quality, public management efficiency index.

\section{Introduction}

Regional image is a set of emotional and rational ideas which result from comparing all regional features, both intrinsic and borrowed from other people's experience, and create a certain image. We should distinguish two basic image components, subjective and objective. The principle objective component of the regional image is a set of competitive strengths and weaknesses, which are driven by regional industry features, export potential availability, distance barriers and traffic infrastructure. Other factors influencing regional image include intellectual and innovative potential along with its ability to meet region development targets, social sphere level, industrial capacity and investment activity (investment volume and qualitative characteristics of investment activities) etc. Competitive strengths undoubtedly intensify competitiveness while certain shortcomings complicate its integration into market space. While investigating competitive strengths we consider it necessary to pay special attention to hidden economy, operating in a certain region. The reason is that scope and feasibility of competitiveness and management quality potential are largely affected by its status.

Admitting paramount importance of interstate and federal bodies in fighting causes and effects of economic crimes, both international and nationwide, we should point out that regional governments possess the potential necessary to affect the black market. If implemented, it can provide entrepreneurial activities legalization, recruit highly qualified stuff for the official labor market, increase budget income, as well as develop social confidence and social capital. In this context quality of public services acts as the key factor to provide social integrity, form group identity, mutual support and team work.

The choice of topic for the study together with its theoretical and practical importance is defined by a number of factors. Among them are: 1) ambiguousness of conceptual framework which describes key phenomena and processes in shadow economy; 2) lack of efficient analytical tools to assess adequately shadow economy; 3) low efficiency of managing meso-scale business activity legalization. These are the main reasons defining the topic of the study, its theoretical and practical importance.

Rules and regularities in regional development as well as methodological approaches to meso-scale management are reviewed in academic literature by L.V. Kantorovich, N.N. Kolosovsky, V.V Leontief, AE. Probst, S.G. Strumilin, A.I. Tartarkin, etc.

\section{Methods}

The subject of inquiry is a system to manage shadow economy using public administration tools. The subject of 
investigation include: business relations emerging in the course of managing regional black economy by using public administration tools. The study is based on theoretical and methodological concepts of fundamental and practical researches in strategic management, regional administration, management decisions development and decision making, managing information systems deployment by the leading Russian and foreign scholars.

A vital factor in hidden economy activation is uniformly oriented policy of regional authorities. It is defined as an activity which implies implementing a set of rights, both legal and illegal, with the aim to appropriate administrative and status rent. The set of rights includes the right on income, or benefits arising from the prior use or permit to use long-term assets given to other agents, who are not entitled to their capital value.

\section{Conclusion}

Shadow economy has a dual effect on aggregated trends in social and economic development of the region. Provided that hidden economy entities act as institutional innovators meso-scale indexes tend to move upwards (which implies decreasing unemployment level, capital inflow, growing total expenditures). If hidden economy entities act as institutional rivals and conservatives meso-scale indexes move downwards (growing inter regional differentiation, brain drain, reducing private investments, decreasing budget income). This implies that public administration needs legitimating in terms of quality change, as well as introducing legal-oriented approach to informal entities, congruent to institutional profile of meso-economic system. Figure 1 outlines the structure of shadow economy [5].

\begin{tabular}{|c|c|c|c|}
\hline & Shadow economy & \\
\hline Informal (non criminal economy) & Hidden economy & \multicolumn{2}{|c|}{ Informal (criminal) economy } \\
\hline & Fancy economy & & \\
\hline & & Organized criminality & Criminal business \\
\hline Legalized economy & Parallel economy & \multicolumn{2}{|c|}{ Illegal economy } \\
\hline
\end{tabular}

Fig. 1. Shadow economy structure

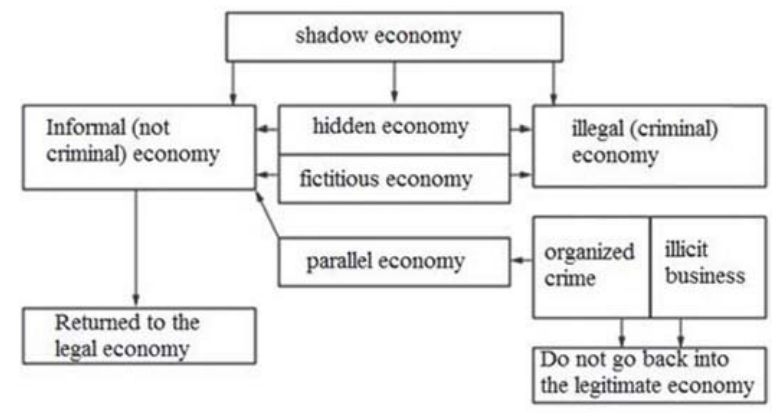

\section{Рис. 1 Структура теневой экономики}

Developing a state regulation system for black economy implies need for elaborate measuring tools to assess management effectiveness and efficiency in the second economy of the region. The suite of metrics used nowadays to assess executive authority performance gives no way to get a full idea of public administration efficiency, effectiveness and quality. There are several reasons for this. First, the list above does not take into consideration development and trends in hidden economy, which in some regions is the dominant element in economic system. Second, the list does not show effectiveness and performance of judicial and legislative power bodies; therefore regional management performance cannot be evaluated in full [4]. Performance evaluation characterizing regional development and its trends, which were conducted in the course of the study, together with correlation assessment of factors selected by experts, made it possible to create a supplementary list. Table 1 shows the supplementary list indicating efficiency, effectiveness and regional administration quality. 
Table 1: Indicators of efficiency, effectiveness and regional administration quality

\begin{tabular}{|c|c|c|c|c|}
\hline № & Indicator & Estimation methods & $\begin{array}{l}\text { Recommended } \\
\text { value }\end{array}$ & $\begin{array}{l}\text { Coefficient of } \\
\text { correlation with } \\
\text { regional indicators }\end{array}$ \\
\hline \multicolumn{5}{|c|}{ Hidden economy development indicators } \\
\hline & $\begin{array}{l}\text { Ratio of hidden economy to Gross } \\
\text { Regional Product }\end{array}$ & $\begin{array}{c}\text { Share of hidden economy can be identified with } \\
\text { the help of disparity method. Ratio to Gross } \\
\text { Regional Product is calculated afterwards. }\end{array}$ & Less than $16 \%$ & $-0,7624$ \\
\hline & Corruption Perception Index & $\begin{array}{l}\text { Calculated according to Transparency } \\
\text { International competent procedure }\end{array}$ & More than 5,1 & $+0,8246$ \\
\hline & $\begin{array}{l}\text { Share of population recognizing } \\
\text { increase in corruption. }\end{array}$ & $\begin{array}{l}\text { Direct questioning according to Transparency } \\
\text { International }\end{array}$ & Less than $10 \%$ & $-0,7523$ \\
\hline & Bribery index & $\begin{array}{l}\text { Calculated according to Transparency } \\
\text { International competent procedure }\end{array}$ & More than 7,5 & $+0,7795$ \\
\hline & $\begin{array}{l}\text { Ratio of latent unemployment to } \\
\text { registered unemployment }\end{array}$ & $\begin{array}{l}\text { Ratio of the unemployed calculated according to } \\
\text { ILO to those listed on the labor market. }\end{array}$ & Less than 1,1 & $-0,8107$ \\
\hline & Efficiency in managing hidden economy & $\begin{array}{c}\begin{array}{c}\text { Share of legalized black economy and its ratio to } \\
\text { regional and local budget expenses to implement } \\
\text { the programme (in a year) }\end{array} \\
\end{array}$ & More than $30 \%$ & $+0,9368$ \\
\hline \multicolumn{5}{|c|}{ Judicial power performance indicators } \\
\hline & $\begin{array}{l}\text { Share of population who trust judicial } \\
\text { power. }\end{array}$ & Direct questioning & More than $60 \%$ & $+0,7242$ \\
\hline & $\begin{array}{l}\text { Share of judicial orders on economic } \\
\text { crimes, where epitomic chapter } \\
\text { coincides with the indictment. }\end{array}$ & Random semantic analysis of judicial orders & Less than $5 \%$ & $+0,8786$ \\
\hline & Fraction of justified judicial orders & Direct questioning by expert community & More than $85 \%$ & $+0,8621$ \\
\hline \multicolumn{5}{|c|}{ Legislative authority performance indicators } \\
\hline & $\begin{array}{l}\text { Fraction of official laws affected by } \\
\text { corruption }\end{array}$ & $\begin{array}{l}\text { Ratio of corruption prone laws (further to the } \\
\text { examination result) to the total number of official } \\
\text { laws. }\end{array}$ & Less than $12 \%$ & $-0,7002$ \\
\hline & $\begin{array}{l}\text { Corrected fraction of corruption prone } \\
\text { laws }\end{array}$ & $\begin{array}{l}\text { Similar to factor } 9 \text {, including relevance of the } \\
\text { taken official laws in economic progress. }\end{array}$ & Less than $5 \%$ & $+0,8963$ \\
\hline & $\begin{array}{l}\text { Efficiency of maintaining legislative } \\
\text { authority }\end{array}$ & $\begin{array}{c}\begin{array}{c}\text { Ratio of the regional income from adopting new } \\
\text { statutes to the expenses to maintain legislative } \\
\text { authority. }\end{array} \\
\end{array}$ & More than $120 \%$ & $+0,8551$ \\
\hline
\end{tabular}

The information provided in the table shows that using the current indexes does not suffice to assess regional efficiency. It should also involve a set of qualitative and quantitative indices to identify trends in regional development, particularly the risk of hidden economy expansion. The fact of substantial impact of the above named factors on regional development is confirmed by the results of our correlation analysis.

To exercise regional administration in the age of globalization and information oriented society which aims to reduce black economy, we need increasing transparency in monitoring and control. Possible solutions include their transfer to the open information area [12]. A current trend aims to bring the information on regional management into the open area, which allows boosting control and feedback efficiency in the field of cooperation between regional government institutions, business society and household sector. However, substantial transparency can be achieved only for a number of final regulation processes. Actually, the data available in open information area are those representing regional and sub-regional management performance, which negates the effectiveness of public management. Therefore we should create a transparent system to monitor and control the performance of regional authorities in all stages including preliminary, running and final control. The system should employ management tools adapted to regional management needs [10].

Information is partly disclosed in the course of preliminary control, when it comes to executing the public procurement law. This information is, however, incomplete. First, it is not comprehensive and often requires specific skills to be extracted. Second, it does not include non financial factors, such as organizational and management procedures, associated with tax payer expenditures, which are currently confidential. To increase management efficiency at the stage of preliminary control we should move the organization and management data into the open information area. The data to 
be revealed include organization and management mechanisms used both by official and enforcement regional institutions to achieve tactical and strategic targets in developing social and economic meso-scale system. Such information being available, overlap of responsibilities among regional authorities will reduce. As a result, the cooperation efficiency between different regional system units will gain momentum, and plans to control regional development process will be possible to revise. At the stage of preliminary control we can thereby reveal potential efficiency enhancement in performance of public management system.

At the stage of running control a supplementary data set should be presented by legislative and executive authorities in the open information area, along with interim accounts. The data set must include trends in providing resources to the corresponding enterprises as compared to target indicators as well as information on effectiveness and efficiency of regional authorities. It is also necessary to create a feedback platform on the respective web pages. As a part of feedback option it is important to provide a possibility to reveal overlapping of management processes and responsibilities among regional authorities. There needs to be a quality evaluation option to assess the exploitation of resources by regional administration as well as the level of customer satisfaction with the quality of public service.

In order to enhance the efficiency of final control, the existing procedures to post the performance data of social and economic meso-scale management system should be expanded by adding two basic data units [7; 9]. The key issue is availability of information concerning deviation of outcomes and expenses from the plan, specifying reasons for the deviation. It is also important to provide full access to methodological administration efficiency and quality database. Such a policy will enable us to identify not only possible improvements in regional development methods and mechanisms, but also constitute methodological tools and approaches to measuring system outcomes.

The factors defining regional image performance can be either subjective or objective. On the one hand they aim to resolve domestic problems related to stabilization and development of the regional social and economic system. On the other hand they define macro partners' attitude to this area. The latter including other regions, federal authorities, general investors, and prospective goods and services consumers.

This study enables us to set out specific features of regional image with an allowance for its dependence on hidden economy:

- intensity (weak, strong, uncertain);

- image status (positive, negative);

- $\quad$ uniqueness (standard, unique, tradition oriented);

- relative stability (stable, unstable);

- controllability (spontaneous, controlled).

In testing regional image all characteristics must be assessed. The following examples of complex characteristics of an image illustrate the intensity of various characteristics. For instance, feebly marked positive regional image might be caused by lack of appropriated accents, to describe the region as appealing, unique, both in terms of business entities' domestic needs and external territories' interests.

A pronounced negative image is a consequence of centrifugal processes in joint organizational culture, and either retrogressive or regressive development of its structural components. Large share of black sector in regional economy leads to substantial transactional expenses in running business. It results in capital outflow, as well as reproductions and structural imbalance. The market does not fulfill its function of allocating resources. Such situation has a negative impact on the regional investment trends. Business entities would rather leave such territories and locate their businesses in more economically comfortable areas.

A stable tradition-oriented image typically emerges in the regions where national, regional and local traditions are dominant. Domestic resources are usually preferred to external ones and access of external business entities to such economic areas is restricted. Such an image can be composed if the share of hidden market is rather large, and its subject continually cooperates with bureaucracy officers, the latter being revenue oriented.

A stable unique positive image normally has one or several dominant traits, which define regional image availability to managing entities as a particular competitive position. An effective system of public administration aimed to neutralize market external effects and prevent opportunistic behavior on the part of public management officers is a prerequisite to form such an image.

These examples demonstrate different ways in which specific features can be detected and identified simultaneously. Regional image making management aims to gain adequate affect on the external environment. High readiness on the part of local commercial entities and the region itself to meet the market requirements, which include measures to manage the hidden economy, is a prerequisite to achieve that outcome.

Regional image testing is a key component in managing regional image making, which can be exercised either online or strategically [7]. If on-line approach is taken, the experts focus on internal factors of regional image. Strategic 
approach to managing regional image making implies conscious steady effort to change specific features of regional image with the aim to increase its competitiveness as compared to other areas. This involves regular comparative testing of regional image and strategic positioning of certain territory's advantages over other territories. Measures to make and develop regional image transform over time within certain territory. They are aimed at long term achievements. The most important aim is to provide regional system sustainability and conditions to balance economic, social and cultural elements in regional development.

\section{Conclusion}

This article has proposed some measures to improve the quality of public management. If these measures are to be implemented, they will have the following effect: decrease in shady employment; ease of administrative restrictions on conducting business; growth in state budget revenues. These changes are the prerequisite for progressive advance in regional economy, raising their residents' living standards as well as creating a favorable regional image.

\section{References}

MacAfee K. A Glimpse of the Hidden Economy in the National Accounts // Economic Trends. 1980. Vol. 136. P. 81-87.

Panasyuk, M.V., Bagautdinova, N.G., Safiullin, L.N., Novenkova, A.Z. Territorial approach to solving the region strategic management problems // World Applied Sciences Journal, 27(13), 2013, 149-153.

Ismagilova G.N., Safiullin L.N., Bagautdinova N.G. Tourism development in region based on historical heritage. Life Science Journal 2014; 11(6s):363-367.

Frey B. S., Weck-Hannemann H. The Hidden Economy as an 'Unobserved' Variable // European Economic Review. 1984. Vol. 26/1. P. 33-53.

Safiullin, M.R., Elshin, L.A., Prygunova, M.I., Galyavov, A.A. (2013). Complex Analysis of Prospects of the Volga Federal District Regions Development: Methodology and Practice. World Applied Sciences Journal 27, 4, 508-511.

Schneider F., Buehn A., Montenegro C. E. New Estimates for the Shadow Economies all over the World // International Economic Journal. 2010. Vol. 24 (4). P. 443-461.

Ulesov D.V., Murtazina G., Safiullin L.N. and Saipullaev U.A. Special Aspects of Development of Business in the Knowledge-Based Economy //World Applied Sciences Journal, 27(13), 2013, pp. 189-192.

Tanzi V. The Underground Economy in the United States and Abroad. Lexington: D.C. Heath, 1982.

Yoo T., Hyun J. K. International Comparison of the Black Economy. Empirical, 1998

Fakhrutdinova, E., Kirshin, I., Kolesnikova, J., Salyakhov, E. The influence of cross-country technological transfer on economic profit formation// Middle East Journal of Scientific Research. Volume 17, Issue 12, 2013, Pages 1632-1634.

Glebova I.S., Sadyrtdinov R. and Rodnyansky D. Impact Analysis of Investment Attractiveness of the Republic of Tatarstan on Fixed Investments of its Leading Companies // World Applied Sciences Journal 26 (7): 911-916, 2013. 
